\title{
Close Encounters with Foreignness
}

Bruce Bennett and Katarzyna Marciniak

'A foreigner in principle is already a spy.'

--Trinh Minh-ha, Surname Viet Given Name Nam (1989)

\section{Encounter 1: Katarzyna Marciniak - Poland, 1970s/1980s}

Before I became an immigrant and thus foreign, and before I received any formal training in the U.S., my early film history education happened almost daily through socialist television, which exposed me to a conventional apprehension of cinematic foreignness. Perhaps assuming that behind the Iron Curtain there was only scarcity of everything, my American peers are always surprised when they hear that I grew up watching 'foreign' films on television by Tarkovsky, Godard, Kalatozov, Bergman, Fellini, Kurosava, Menzel, or Sturges that were shown under the banner of 'Kino interesujących filmów' [Cinema of Interesting Films], 'W starym kinie' [In an Old Movie House], or 'Filmoteka Arcydzieł' [Masterpiece Cinematheque]. They are specifically surprised to learn that this education happened through the medium of television. My favourite pastime was watching westerns with my father on Sunday nights (we both loved The Magnificent Seven (Sturges, 1960) and relished spaghetti westerns like The Legend of Frenchie King (Christian-Jacque, 1971) with Brigitte Bardot and Claudia Cardinale), or silent comedies with Chaplin or Keaton. In my memory, televison programming did not include many films by international female directors, though Márta Mészáros's films were certainly shown, and audiences were occasionally offered films by Polish female filmmakers such as Agnieszka Holland, Wanda Jakubowska, or Barbara Sass. My U.S. students might claim that I had access to a fairly elitist film education early on, but for my generation and those of our parents and grandparents, our media habits and cultural knowledge were shaped by the limited programming of one and eventually two TV channels.

I tell this story because at a time in socialist-era Poland when the possibility of crossing borders was limited and heavily controlled, encounters with various cinematic cultures on TV, in the intimate setting of one's home, were powerful transnational encounters offering amazing forays into the world. This may not be so surprising since we lived during the era that honoured Lenin's famous saying that 'of all the arts the most important for us is the cinema' (Seventeen Moments in Soviet History, 2015), and Łódź where I grew up has been known as HollyŁódź because it was home to the prestigious Polish National Film School and the country's motion picture industry. Simultaneously, television broadcasting, like other arts, was censored, supposedly shielding the public from ideologically 'dangerous' western materials. Thus, while my generation routinely watched Mikhail Kalatozov's The Cranes Are Flying (1957), Stanislav Rostotsky's The Dawns Here Are Quiet (1972) and other Soviet-bloc productions, we were also exposed to a rich 
selection of foreign films that extended to Ingmar Bergman's Persona (1966), Roman Polanski's Repulsion (1965), or Alan J. Pakula's Klute (1971), all apparently acceptable since the censors regarded them as portrayals of a dejected, deranged, and degenerate West..

\section{Encounter 2: Bruce Bennett - UK, 1970s/1980s}

My own cinematic education, on the other side of the Iron Curtain in the UK, was remarkably similar. Growing up in the 1970s with three television channels and later, from the early 1980s, a fourth, in a town outside London with just a single second-run cinema, my introduction to world cinema was primarily through television. With a limited range of options, I watched whatever was on TV, often by myself. As far as I can recall much of this comprised wearyingly awful British comedies, interminable WW2 action epics, Laurel \& Hardy and Harold Lloyd shorts, Hollywood westerns and musicals, Tarzan series, science fiction B-movies and Elvis exploitation pictures. However, my film-viewing extended to the perplexing, intriguing foreignness of Tarkovsky, Kieślowski, Bergman, Kurosawa, Kobayashi, Schlöndorff, Truffaut, Antonioni, Satyajit Ray and Peter Weir. British television was also my introduction to such singular British filmmakers as Nicolas Roeg, Ken Russell, Peter Greenaway and Derek Jarman. The strangeness of all of these films - British and American films no less than any others - was partly due to their intrinsic qualities, but this was heightened by their incongruous proximity to the banal material constituting the bulk of the schedules: sports coverage, light entertainment, news, reportage, religious and educational programming and chat shows.

The characteristic structural property of broadcast TV that Raymond Williams termed 'flow,' the relentless Eisensteinian collision of thematically and stylistically different categories of material, results in a dynamic field in which every film, programme or sequence is subdivided into segments which are situated in a stream of tonally disjointed sequences (Williams 2004, 77). One consequence of this mobile context is that all material screened on TV is rendered strange or foreign since it has a tenuous, unstable relationship with the sequences around it, although, as Williams observes, this programmed flow is far from incomprehensible and the emerging structures can be regarded as expressions of 'the meanings and values of a specific culture' (Williams 2004, 120). Nevertheless, the perpetual recontextualisation that takes place in broadcast TV ensured that for this British viewer in the 1980s, King Creole (Curtiz, 1950), The Human Condition (Kobayashi, 1959-61), The Chessplayers (Ray, 1977) and Jubilee (Jarman, 1978) were all similarly, lingeringly 'strange.'

The parallel between these two stories points us towards some initial conclusions. One is that late twentieth-century TV broadcasting operated in different national contexts according to the shared principle of using films sometimes almost arbitrarily as cheap schedule-fillers, but also with an understanding that broadcasters were responsible for providing cultural education as well as entertainment, exploiting the limited range of options available to viewers in order to expose them to 'art.' This 'public-service' ethos was also imposed upon UK commercial channels through the conditions of the broadcast licence. Another conclusion is that, as Derek Jarman 
observed in his autobiographical reflections on cinema and art, 'One can know the whole world without stirring abroad' (Jarman 1993, 112). Cinema was our introduction to a wider world, to 'foreign' cultures both local and distant. And this is where we meet, both fascinated with the idea of foreignness in its multivalent dimensions.

Our personal histories of studying film are also histories of the engagement with shifting media technologies. We have watched the films that we teach, write and think about on a variety of screens from black-and-white TV sets in bedrooms to IMAX cinemas. Thinking about film requires us inevitably to reflect upon the material culture of cinema, the social practices of film viewing that shape its meaning, and the economic systems that cinema is the expression of, and transnational films make these contexts implicitly visible. When we encounter transnational cinema, we often find ourselves watching these films in a variety of formats - dubbed and subtitled, cropped or masked, edited and bowdlerised. Far from being inauthentic or incomplete approximations of an original, however, these multiple versions make visible the transformations a film undergoes as it circulates, foregrounding the 'echoes, kinks, gaps and refractions' that, Bhaskar Sarkar observes, abound in transnational cultural circuits $(2010,35)$. In other words, a further value of studying transnational cinema is that it invites us continually to look not just at the dematerialised 'content' of particular films, but to look at the screens, formats and frames themselves. In drawing our attention to the surfaces and interfaces of cinema, transnational films invite us to focus upon the process of mediation.

\section{Encounter 3: Phenomenology of Cinematic Foreignness}

'Every film is a foreign film, foreign to some audience somewhere - and not simply in terms of language,' write Atom Egoyan and Ian Balfour (2004, 21). We cited this point in our Introduction to the special issue of Transnational Cinemas on 'Aporias of Foreignness' because of an interest in disassociating the notion of the 'foreign' from stereotypically apprehended otherness to claim that spectatorial encounters with cinema always, to some degree, involve an encounter with the unfamiliar that is both challenging and enlightening (Marciniak, Bennett, 2018 , 4). The value of studying transnational films is that they draw our attention to these encounters in an especially complex, unsettling, and self-referential manner, inviting us to reflect upon the limits of our comprehension of certain narratives. Misunderstanding and misreading is a common thematic focus in transnational cinema, for instance, which is often articulated through the plot device of the encounter (and the missed encounter). Unlike the romantic encounters in Hollywood films that carry the promise of plenitude and ultimate satisfaction, encounters in transnational cinema are always mediated by distance or language, and are typically characterized by translation problems and misrecognition, delays, and doubt. Thus transnational cinema is shot through with radical scepticism about the future while inviting a spectatorship that demands that we think about the future in terms of ethical encounters with others - in terms of an ethics of answerability that resists subsuming difference through appropriation or reducing difference to sameness. ${ }^{1}$ One consequence of this is a cinema of nervous spaces, depictions of 
bodies and landscapes that elicit critical nervousness, or what Patricia Yaeger once called 'textual anxiety' (Yaeger 1997, 241).

For us, as scholars who have contributed to the field by foregrounding the aesthetics and politics and pedagogical challenges of transnational cinema - particularly the representations of immigrants, migrants, and refugees, national (un)belonging, border-crossings, and the construction of border zones as sites of contention - the point that Egoyan and Balfour make feels almost counterintuitive. This is because, having focused our interrogations on the figure of the displaced foreigner and on the modalities of foreignness - the ways in which foreign bodies are variously welcomed, questioned, examined, punished, exploited, or expelled - our impulse is to work against risking the dilution of this concept into something vague or universal, such as a celebration of fluid, cosmopolitan foreignness that is oblivious to inequalities of wealth, mobility, privilege, and voice. However, a conceptual relocation of foreignness is important because of the term's valence in cinematic history. As Elizabeth Ezra and Terry Rowden, for example, argued about the term 'foreign film':

In the U.S. and the U.K. this term has functioned primarily as a signifier for non-English language films. Practically it has served to relegate those films, and the force of their images of cultural alterity, to the so-called "art-house circuit" and to the select audiences that frequent them [....]This phenomenon has served to reinforce the notion that U.S. cinema is the site of entertainment (i.e., a commodity that people are willing to pay for), while other cinemas are sites of instruction or edification (a non-commercial art form to which people submit, with varying degrees of reluctance, or, at best, as sense of cultural duty, in the classroom or the heavily subsidized specialist cinema) (2006, 2-3).

It is clear that the idea of the 'foreign film' is ideologically charged and associated with specialized audiences. In our experiences, these tensions manifest themselves most strongly in our pedagogies as our students, encountering cinematic worlds that are ostensibly removed from their lived realities, grapple with the phenomenology of the unfamiliar. ${ }^{2}$ And, since our recent work on transnational cinemas focuses on border traumas, refugee narratives, and violent displacement, classroom encounters with often very difficult films tend to become conceptual battlegrounds, testing the limits of spectatorial comfort and knowability. Discussions of racial politics, the ambivalence of hospitality, the treacherousness of globalization, economic exploitation, immigration, and the liminality of foreignness challenge all of us, teachers and students alike. As Katarzyna has argued, transnational cinema is a particularly potent object for such explorations because it foregrounds discomfort, implicating students and teachers in the inequalities of the world system and emphasizing the ethical quandaries of cross-cultural spectatorship (Marciniak 2016, 271). And this discomfort, as Bruce has claimed, is certainly exacerbated by the fact that 'foreignness is not a matter of intrinsic difference or essential identity, but of dynamic relationality' that spectators are obliged to confront (Bennett 2018, 20). 
Introducing our students in our recent courses to such films as Ai Weiwei's Human Flow (2017), Bahman Ghobadi's Turtles Can Fly (2005), Angelina Maccarone's Unveiled (2005), Mohsen Makhmalbaf's Kandahar (2001), or to Another Kind of Girl Collective's experimental shorts made by young women in Jordan's Za'taari refugee camp, pushes us to engage with questions of legibility, audibility, and visibility that pertain to refugees' lives depicted onscreen. We are obliged to encounter foreignness head-on. As our students often claim, commenting on the complexities of what we have called an 'enduring spectatorship,' we are engaged in the distressing difficulty of watching such narratives and nevertheless are convinced of the necessity to see them (Marciniak, Bennett 2018, 8). As spectators, we are often engaged in a 'suture without release,' a metaphor theorizing spectatorial experiences of being immersed in the viewing process without reprieve (Marciniak 2005, 30). And, of course, the pedagogical encounter with foreignness encompasses teaching cinema history; in teaching and discussing historical films, we are reminded again and again of L.P. Hartley's observation that 'The past is a foreign country. They do things differently there' $(1953,17)$.

\section{Encounter 4: Cold War: Translating Foreignness}

In summer and fall of 2018, we both saw Paweł Pawlikowski's new feature, Cold War (Zimna wojna), in Gdynia, Poland, and Lancaster, UK, respectively. Pawlikowski's films have preoccupied us for some time now: because of his Polish-UK biculturality and the focus in his work on problematizing questions of singular national identity; because of his 2013 film Ida (Poland's first Oscar in the category of the Best Foreign Film), boldly showcasing the complexity of Polish-Jewish relations; and because of his interest in transnational encounters, foregrounded in films such as The Woman in the Fifth (2011), a Kafkaesque co-production about an American literature professor stranded in Paris that recalls Roman Polanski's The Tenant (1976). Pawlikowski's first feature film, Last Resort (2000), tells the story of a Russian woman, Tanya, who finds herself categorized as a 'bogus refugee' in the UK, trapped in Margate, a seaside resort town that is the site of a refugee centre, a paradoxical location that conveys conflicting feelings of openness and suffocation. One of the most interesting aspects of that film for us is the idea that for someone from the east, Western Europe is not viewed uncritically as the promised land; at the close of the narrative, Tanya leaves Britain voluntarily. ${ }^{3}$ While Last Resort is interested in staging encounters with foreignness across borders and in upsetting the assumed hierarchy of east and west, Cold War complicates this thematic further by defamiliarizing the very idea of the foreign. The fact that this Polish-British-French co-production has received the Best Director award at the Cannes festival, Best Film award at the Polish Film festival, and has been nominated for numerous others, means that the narrative's focus upon border-crossing is restaged or modulated in the history of the film's production and circulation.

Cold War is a film about close encounters and estrangement, migration, exile and homecoming. The title refers both to the narrative's historic context, and also to the tensions underlying the romantic relationship at the centre of the film, as the protagonists, musician and composer Wiktor (Tomasz Kot) and gifted singer Zula (Joanna Kulig), are repeatedly separated and 
reunited in different locations around Europe during the 1940s and 1950s. By staging such transnational encounters, the film shows the contentious nature of border-crossings for characters from the east, crossings that are sometimes complexly difficult, sometimes surprisingly easy. These encounters are episodes in a tragic relationship shaped by class divisions, politics, gendered prejudices, and performance. Cold War displays a self-conscious preoccupation with artifice and reproduction, so that at one point we see Wiktor in a Paris studio recording the score for an Italian horror film, and the film itself is shot in pristine black and white and presented in academy ratio, anachronistic stylistic choices that stress its affinity with Polish films from the period in which the narrative is set; in part, the film is a reflection upon cinema. More directly, the shifting boundary between authenticity and simulation is at the core of the troubled romance between Wiktor and Zula since he first encounters Zula when she auditions to join the song and dance troupe he will lead. As she waits her turn, another woman explains that the panel wants a 'peasant-style' performance, and so, acting upon this tip, what Zula presents to Wiktor and his colleagues from the beginning is a knowing, skillful act. It is suggested that she may not, in fact, be the genuine 'peasant' that Wiktor and Irena are searching for, and so Cold War reminds us that all relationships involve degrees of translation, dissimulation, and misreading.

Underlying the fatal romance between bohemian musician and pragmatic muse is a thematic exploration of the complicated relationship between culture and identity. The film examines the way that rural folk music is appropriated and homogenized, reformatted as the governmentsponsored expression of authentic, ethnically pure cultural heritage that will give the newly formed communist state the legitimacy of tradition. As the narrative opens, we see three individuals, Wiktor, Irena, and their driver Lech, travelling through the Polish countryside in search of inspiring folk songs and performers they plan to recruit for the folk group Mazurek (recalling famous folk group Mazowsze). Irena and Wiktor appear to be motivated by a genuine interest in folk art, while Lech is soon revealed as a surveilling eye for the secret police.

However, although they regard Lech with suspicion and condescension, it becomes clear that all three of them are agents engaged in the same patriotic project of cultural appropriation.

The first shot of the film encapsulates the tensions that the narrative explores. It begins with a close-up of a man's rough, peasant hands playing the bagpipes and the camera tilts up to show the performer's threadbare clothing and a face with uneven teeth and remarkable pale eyes (Figure 1). He begins to sing, staring intently at the camera that then pans around to show a second musician accompanying him on the violin. The violinist continues the song, also staring directly at the camera and then, as he resumes playing his instrument, the camera pans again to show a little boy standing a few meters away in the snowy farmyard, studying the two men and the camera suspiciously. The only one of its kind in the film, this confrontational documentarystyle image establishes the thematic centrality of recording or documentation for the film, and it also functions as an acknowledgement of the extractive cultural violence in which Wiktor, Irena, and Lech are engaged. Although the two musicians are performing for the camera/spectator, there is nothing ingratiating or welcoming in their rendition. They look at the camera with 
resentment and defiance, as if playing under duress, conscious that they are being scrutinized by an official, othering gaze that regards them as curiously foreign, and fully aware that their music is being taken from them. The shot positions Irena and Wiktor and, by implication, the film's viewers, as outside observers subjecting the musicians to an objectifying touristic gaze, a spying eye. It also positions song at the centre of the film.

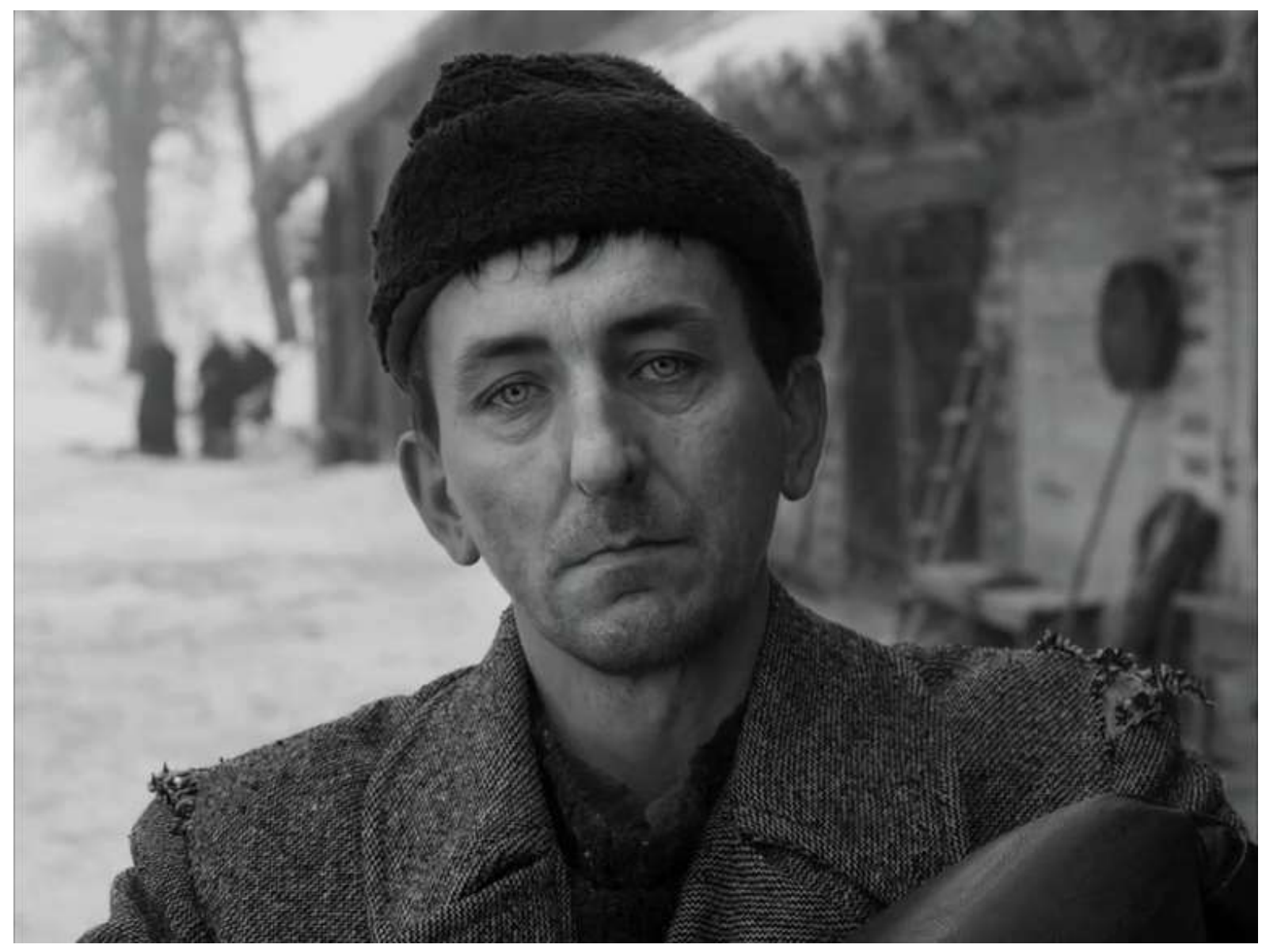

Figure 1. Two eyes, one song. Foreignness in close-up. An anonymous folk musician plays and sings in the film's opening shot.

Shortly afterwards, as Wiktor and Irena sit over a tape-recorder in their military truck, smoking and listening back to songs they have captured, Lech comments from the driver's seat, 'It's nice. What language are they singing in ${ }^{4}$

Wiktor: In Lemko.

Lech: That's what I thought. Too bad. 
Wiktor: Why?

Lech: Because it's not ours.

This brief exchange reinforces the idea of music as an expression of cultural identity, but also foregrounds the idea of nationhood as a site of contention. Łemkowie (Lemkos in English) is an ethnic minority group in Poland, a constitutive component of the nation's multicultural history that Lech refuses to recognise. He reiterates this idea later when, during a performance by the Mazurek women, he asks Wiktor: 'don't you think we need to do something about Janicka?' 'Her features are too dark' he observes. 'Look at her eyes' (which, for Lech, are an irreducible sign of racialized identity). He explains that, 'our group is supposed to be a folk group, Polish, typically Slavic,' but he eventually agrees to keep the singer, proposing that 'we will have her hair dyed.' It is a chilling exchange since Lech's desire to cleanse the singer of her visible ethnic difference in order to reproduce an image of 'authentic' Polishness reminds us of the historical political violence that has followed from singular concepts of national, ethnic, or cultural identity in $20^{\text {th }}$ century Europe. It is an example of the way the film continually puts ideas of authenticity into question, drawing a parallel between musical performance and the performance of nationhood (both of which involve simulation, masquerade and degrees of enthusiasm or reluctance). Of course, the grim irony is that the bodies, dialects, and cultures Lech regards as troublingly different, are intrinsic elements of what he imagines is an authentic national identity as expressed by the costumes and music of Mazurek, the group that goes on to showcase the 'priceless treasures of national culture' in international performances.

This theme of internal foreignness - of nations intersected by regional, ethnic, and classed identities - is a theme that runs throughout Pawlikowski's work as far back as the early TV docudrama Twockers (Pawlikowski, Duncan, 1998), a study of teenage children roaming a Yorkshire housing estate, scraping together cash by selling property stolen from cars and houses. ${ }^{5}$ Completely unsupervised by adults, abandoned by institutions, the children run amok, setting off fireworks, destroying property, and speaking in their own invented language, a barely comprehensible form of Pig Latin that requires subtitled translations.

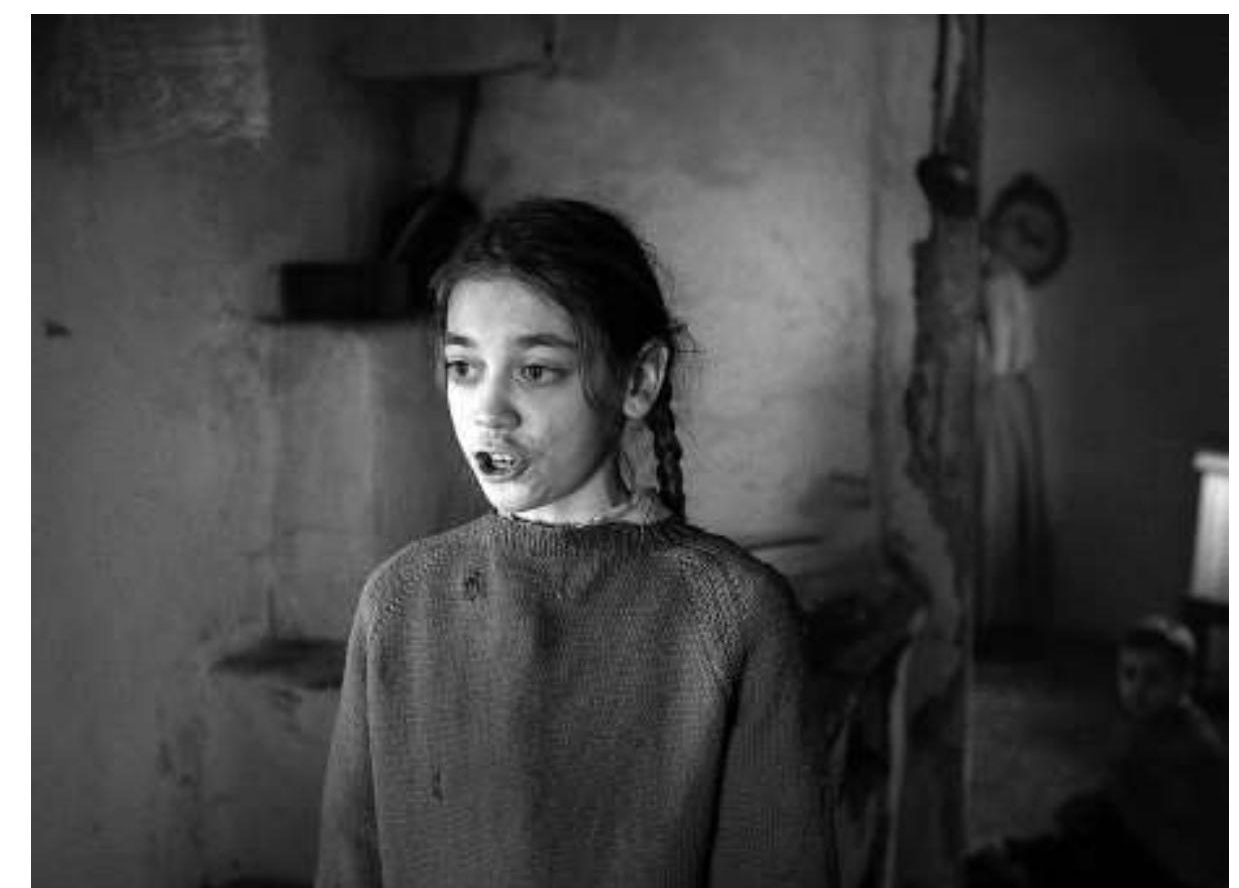


Figure 2. A peasant girl sings the folk song 'Two Hearts, Four Eyes' while Wiktor and Irena record her performance.

The narrative structure of Cold War is fractured and itinerant, conveying a sense of the precariousness of the romance between Wiktor and Zula. The episodic story begins in Stalinist Poland (1949) and takes the viewers to Germany (1952), France (1954 and 1957), and Yugoslavia (1955) where the Mazurek troupe performs internationally, while Lech rises to the position of manager. But, in our analysis, one of the key transnational protagonists is a song documented by Wiktor and Irena. We first encounter it at the beginning of the film, when a young peasant girl sings 'Two Hearts, Four Eyes' a cappella in a local dialect (Figure 2). Once appropriated, arranged, and translated by Wiktor, the song becomes the leitmotif. It exemplifies the generative mechanisms by which music, films, and other texts circulate through different contexts, taking on new meanings while other connotations recede and are obscured. At once familiar and foreign it exemplifies the theme of border-crossings and the turbulent entanglement of Wiktor and Zula in a relationship that ends in a suicide pact. While the title emphasises again the theme of observation introduced in the opening shot, 'Two Hearts, Four Eyes' is also a lament about unrequited love and impossible encounters, addressing the bearer of 'Dark eyes, and your cries that you cannot meet.'

The song is reprised in a lush rendition by Mazurek in Warsaw in 1951 where a banner outside the concert hall displays the three terms in whose service the group performs: 'Party-NationFatherland'. Mazurek has been instructed to introduce new songs celebrating the 'worldly proletariat' and 'agricultural reform,' and their ideological devotion is emphasized spectacularly in a subsequent concert when an enormous portrait of Stalin is slowly raised behind them as they sing (Figure 3). In another instance of cinematic intertextuality, the scene cites Jerzy Skolimowski's 1967 Hands Up! (Ręce do góry) and thereby taps into a history of socialist cinematic dissidence (Figure 4). Banned for over two decades in Poland, Skolimowski's film features a famously offensive scene in which students of the Union of Polish Youths (Związek Młodzieży Polskiej, ZMP) display a similarly huge satirical poster of Stalin in which the leader has been given two pairs of eyes in a brazen metaphor for Stalinist surveillance. 


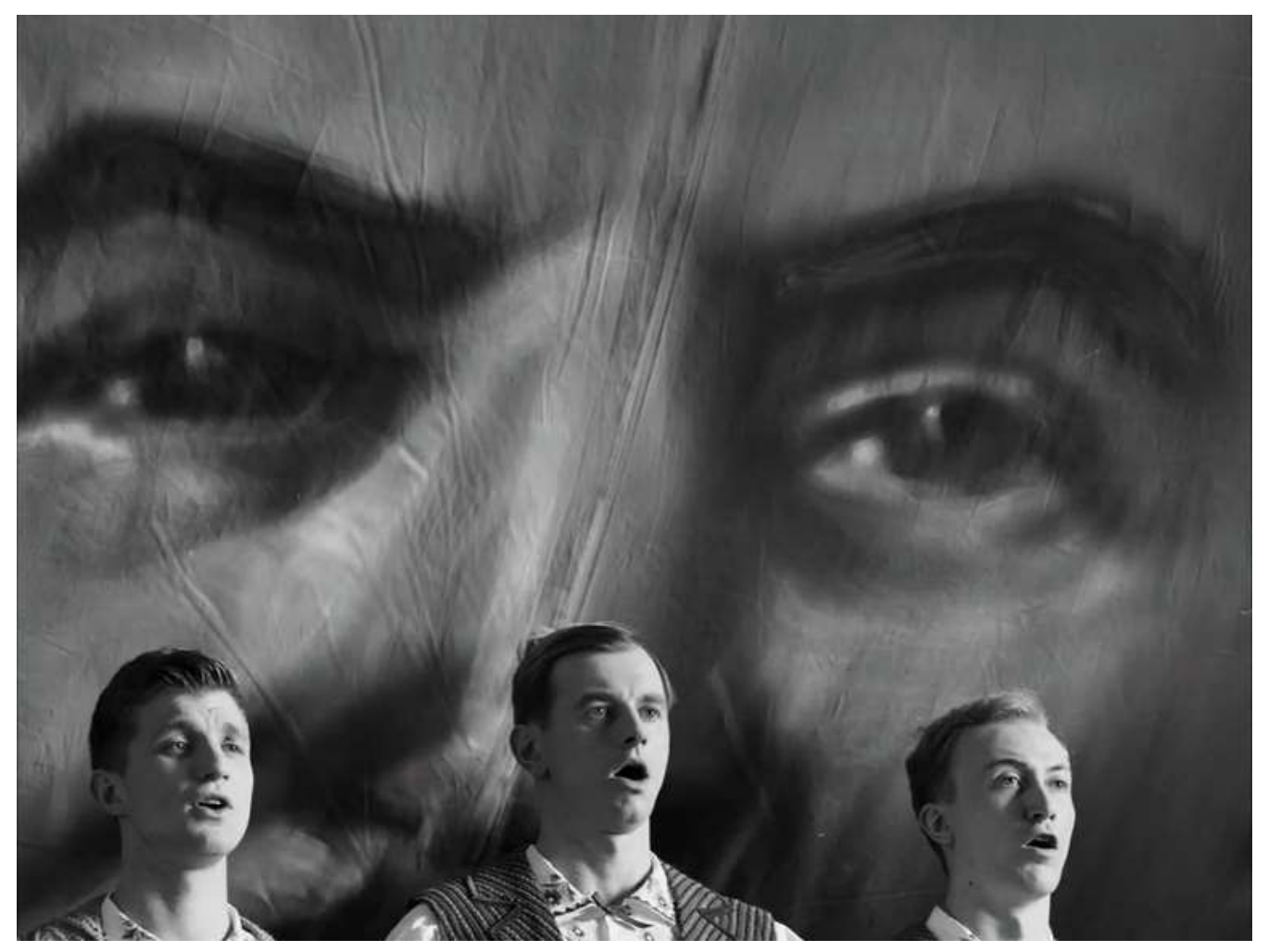

Figure 3. Many voices, Two Eyes: A banner of Stalin is raised as Mazurek performs on a concert hall stage.

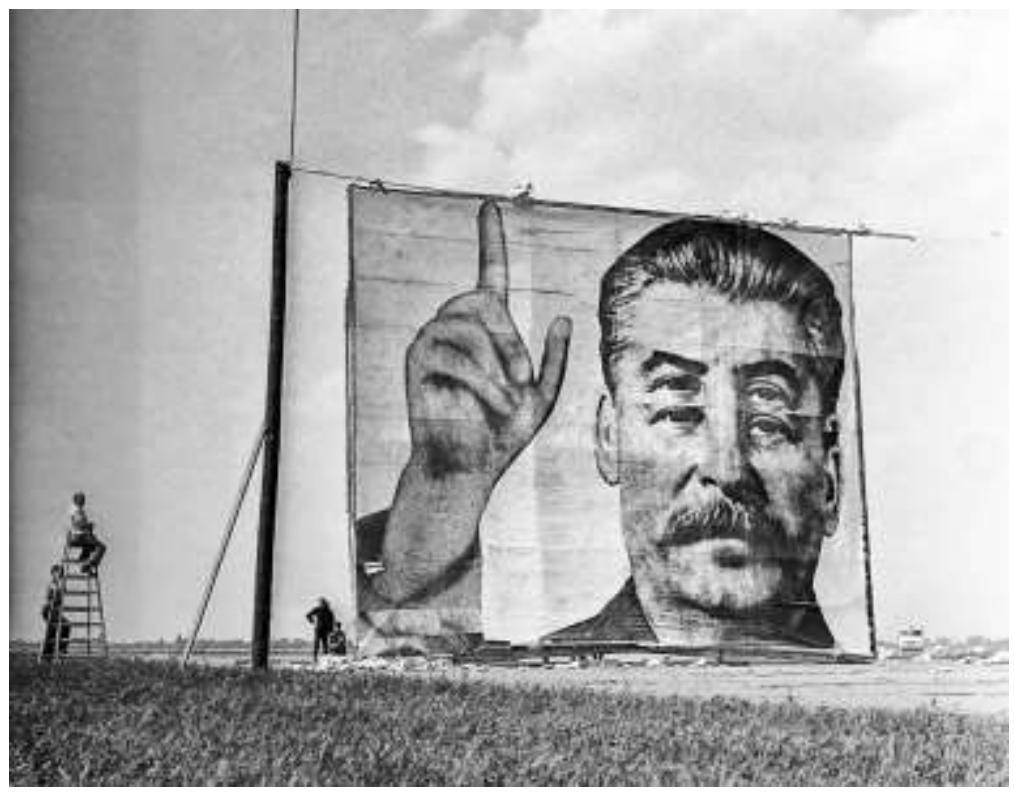

Figure 4. One leader, four eyes - the scandalous banner of Stalin in Hands $U p !$

After Wiktor defects to Paris, where he finds work as a musician, Zula joins him, and this narrative development is marked by a further modification of the song. When Zula sings 'Two 
Hearts, Four Eyes' to a rapt audience in a jazz club with Wiktor's band, her delicate reappropriation of this traditional folk song transforms it from patriotic kitsch into a personal expression of longing. It has undergone radical stylistic change by this point, but it is the song's eventual French-language variation that is most troubling to Zula. Now embedded in an artistic milieu, Wiktor commissions a translation of 'Two Hearts, Four Eyes' from a poet friend in the hope that it will establish Zula's singing career. She is incredulous at the effect of this transformation, which substitutes her interpretation of the text with that of another woman: 'I wonder who translated this? Don't tell me it's your literary friend. What a dumb text.' When Zula and the female poet encounter one another at a bourgeois party, Zula finds herself cast yet again as a peasant - albeit this time, on the basis of assumptions about the inferiority of eastern European culture. The condescending writer assumes that Zula must be 'shocked' by France with its 'cinemas, cafes, restaurants, shops,' but Zula retorts, 'between us, I had a better life in Poland.'

Zula reluctantly agrees to record the song, but when Wiktor presents her with the finished record, she throws it across the street, dismissing it as 'empty,' and describing it bitterly as their 'bastard.' As Edward Said once remarked, referring to the performance of exilic consciousness, 'clutching difference like a weapon to be used with stiffened will, the exile jealously insists on his or her right to refuse to belong' $(2003,182)$. In our reading, it is clear that Zula is indeed 'clutching [her] difference like a weapon,' defiantly refusing the acculturation and commodification of her foreignness, and also stubbornly refusing Wiktor's repeated attempts to cast her in the role of vessel or mouthpiece for somebody else's words.

As 'Two Hearts, Four Eyes' migrates across national and stylistic borders, channeled by different singers, it voices a critique of both worlds. The narrative refuses to privilege either side of the Cold War, reflecting mournfully upon the mutually destructive consequences of irreconcilable separation. The close encounters with the idea of the foreign on both sides of the Iron Curtain work to dismantle the binary thinking that one of these worlds was more politically and creatively free. Significantly, neither character can find a home in Paris. Zula feels stifled in France, conscious that Wiktor is exhibiting her foreign femininity as an exotic novelty, and after she returns to Poland, Wiktor goes to the Polish Consulate in France to request permission to follow. His sense of unbelonging is confirmed by the consul: 'You are not French, not Polish either. As far as the Polish People's Republic [Polska Ludowa] goes, you don't exist.'

However, he explains that a potential solution exists if Wiktor is sufficiently regretful, and the next encounter comprises Zula visiting Wiktor in what appears to be a prison, or a detention camp in Poland. His head is shaved, his fingers mangled from a presumed torture (suggesting his career as a musician is over), and he says little as Zula takes him in her arms. Now married to Lech, with a child, drinking heavily and singing with a terrible Mariachi band, she is able to pull some strings and arranges for Wiktor's release. Thus, following the conventions of the classic melodrama, the unequal power relationship between them has been reversed as Zula takes the shattered musician under her wing. 
Rather than an improbably happy reconciliation, the film ends with quiet tragedy. The reunited couple take a bus into the countryside where they visit a ruined, roofless church and pray together before each swallows a handful of pills. There is a moment in the church that offers a stirring image that lingers in our memory of the film, a static close-up of a crumbling fresco in which two eyes are still visible (Figure 5). The shot invokes the iconography of Andrei Tarkovsky's films, most evocatively present in Andrei Rublev (1966). Given Tarkovsky's status as exilic foreigner outside the Soviet Union and his well-documented history of dissidence, this subtle reference invites a concluding meditation on art and its relation to borders, on the insidious power of the nation, and on cinema itself - the expression, in Tarkovsky's words, of 'sculpting in time' (Tarkovsky 1987). As eyes frame Cold War, the narrative shows how such a sculpting in time unfolds itself: the shot of the fresco is a repetition since it first appears near the beginning of the film when Lech wanders into the church. By the time we see this image a second time, it has acquired the weight of a metaphysical gaze - an echo that reverberates insistently, like an ocular specter haunting the narrative.

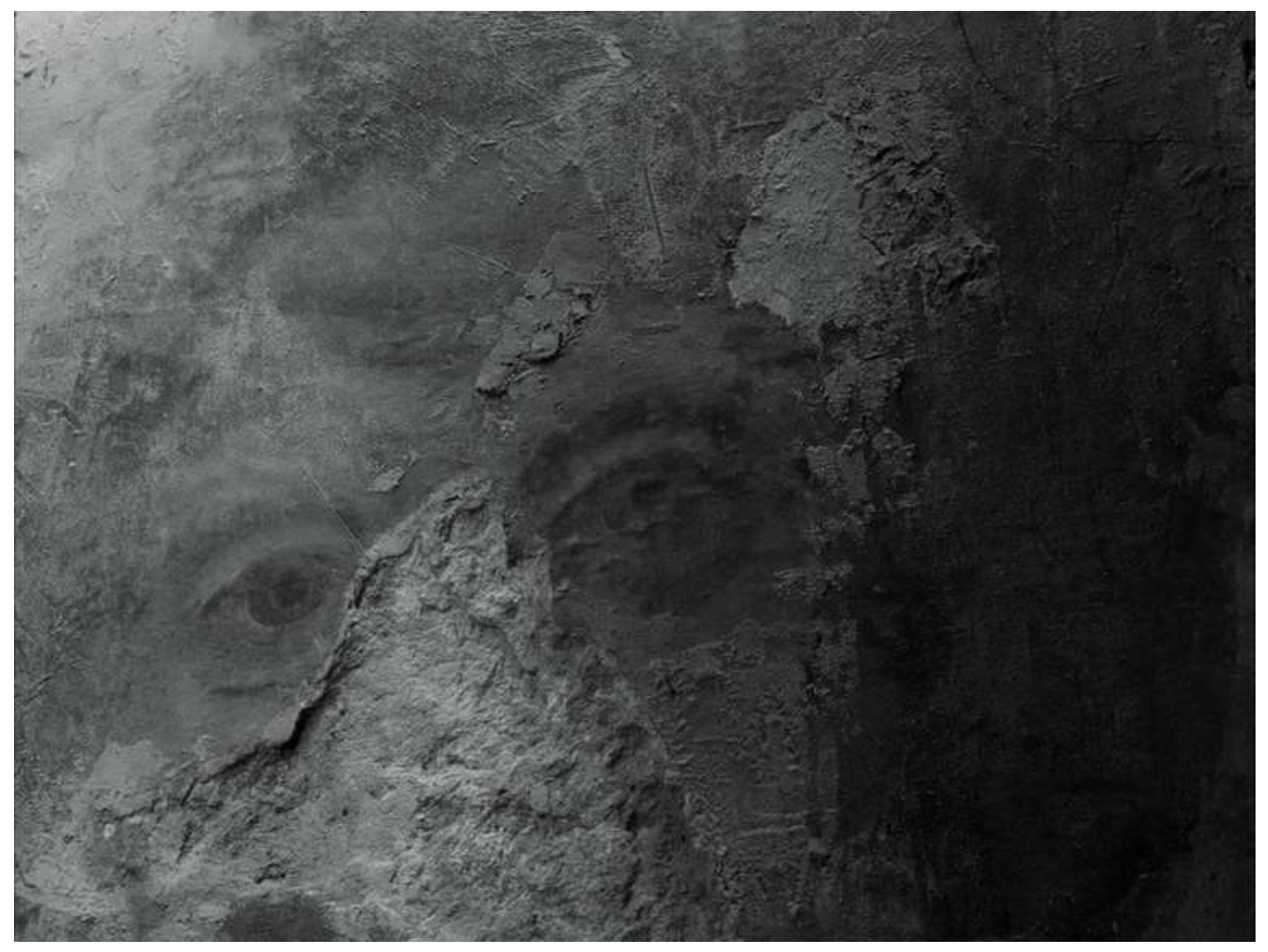

Figure 5: Two shots, four eyes - a close-up of the wall painting in an abandoned church which appears at the beginning and end of the film. 
In the film's final moments, as they wait on a roadside bench to die, Zula suggests to Wiktor, 'Let's cross to the other side. It has a better view,' and they walk across the road, leaving an empty frame. The invitation reprises this self-reflexive film's preoccupation with both bordercrossings and observation (and with eyes and 'eye-dentity'), but it also restates the invitation made by the 'foreign' films that fascinated us as we were growing up. A curiosity about the view on the other side underlies the desire that draws us repeatedly into close encounters with film, but whereas many films make promises of unrestricted pleasure that they can never deliver on, the better view offered by transnational films is something more modest and far more important: a different perspective, and a perspective that insists upon the importance of difference.

\section{Encounter 5: Encountering Difference - Another Cinema, Another World}

Cold War offers a subtle critique of nationalistic ideologies and various purification impulses on both sides of the Iron Curtain. It returns us to a period of tense political divisions, reminding us of the power of the Berlin Wall and its performance of exclusions, stigmatizations, and desires. In this context, it is worth remembering Stuart Hall's apt formulation:

The Berlin Wall, monstrosity that it was, did set up a kind of barrier, real and symbolic. Its awesome brick visage carried a message: 'Beyond this frontier is another kind of Europe, another system, another world.' In a way this reinforced certain old European preconceptions, for the 'real' Europe has always imagined over there as elsewhere, other, the beyond: the frozen wastes, wolves roaming the icy slopes, the mysterious east, barbarians clamoring at the gate of civilisation. $(1992,46)$

The power of Cold War rests in its exploration and refutation of such stereotypical thinking, since the opening scenes suggest that 'the mysterious east' contains its own 'mysterious easts,' while for Zula and Wiktor the 'real' Europe lies somewhere other than the French capital. Notably Cold War ends, just like Ida, with its protagonists walking along a road in the Polish countryside, still searching for new heuristic possibilities, beyond the confines of reductive binary dichotomies. This desire for a new perspective and a 'better view,' in the current political climate of intense nationalisms - and the new ultra-conservative government in Poland certainly exercises such nationalism with frightening vigor - and a global rise of xenophobic and racist sentiments, invites an urgent contemplation of difference and its value in the present moment.

In following the movements of Zula and Wiktor around Europe and back and forth across the Iron Curtain, Cold War tells this story with a certain ambivalence. Its depiction of Communist Poland complicates familiar literary and cinematic depictions of Eastern Europe as a monolithic paranoid, totalitarian state (although the violence of the system is not effaced). There is a certain nostalgia for the period, which is evident in the film's careful pastiche of film style from the 1940s and 1950s and its interest in folk traditions as well as smoky Parisian jazz clubs.

Moreover, what the couple find when they head West over the frontier in search of 'another kind of Europe, another system, another world,' is a system that is less radically foreign than they had imagined. It is a world that remains structured around class and gender inequalities. Crossing to 
the other side has afforded them a better view of France and the West, but also of the Poland they left behind.

In revisiting a Europe that was divided by the Iron Curtain, Cold War reminds us that while the Wall may have been brought down in 1989, the message it broadcast still persists. Rather than disappearing with the collapse of Eastern bloc communism, the frontier shifted, and Europe continues to fantasise that it is beset by marauders coming from elsewhere. The value of the film is that, like much of the rest of Pawlikowski's body of work, it insists that this imaginary foreignness is not located somewhere over the horizon (or in a distant past), but is a constitutive component of local and national cultures. In the context of current political divisions that try to vehemently fend off difference and meet it with violence at the border, we are reminded of Trinh Minh-ha's point about letting 'difference replace conflict' (2001, 930). Trinh's point feels deceptively simple, yet this is the ethical challenge that transnational cinema obliges us to engage with beyond current empty institutional slogans of 'embracing difference.' The value of transnational cinema is also that it invites us to see how even apparently familiar cultures are repeatedly transected by difference, the mediating system of film storytelling allowing us to look anew through foreign eyes.

${ }^{1} \mathrm{I}(\mathrm{KM})$ explored this issue in depth in "Pedagogy of Anxiety" in relation to a spectatorial witnessing of traumas in the context of Mandy Jacobson and Karmen Jelinčić's 1996 documentary, Calling the Ghosts.

${ }^{2}$ We discussed transnational cinema pedagogy in our introduction to Teaching Transnational Cinema: Politics and Pedagogy.

${ }^{3}$ As one review claims, Last Resort is an 'un-British' film (Gibbons 2001).

${ }^{4}$ Translations from the Polish are mine (KM) as the DVD released in October 2018 for the Polish market lacks English subtitles.

${ }_{5}^{5}$ Twockers is a slang term for car thieves, derived from the UK legal acronym: TWOC, 'taking without the owner's consent.

\section{References}

Bennett, B. 2018. "Becoming Refugees: Exodus and Contemporary Mediations of the Refugee Crisis." Transnational Cinemas 9 (1): 13-30.

Duncan, I. and P. Pawlikowski, dir. 1998. Twockers. UK: BBC Films.

Egoyan, A., and I. Balfour. 2004. "Introduction.” In Subtitles: On the Foreignness of Film, edited by A. Egoyan and I. Balfour, 21-31. Cambridge, Mass and London: MIT Press.

Ezra, E. and T. Rowden. 2006. “General Introduction: What is Transnational Cinema?” In Transnational Cinema: The Film Reader, edited by E. Ezra and T. Rowden, 1-12. London and New York: Routledge. 
Gibbons, F. 2001. "Meet me in Margate." The Guardian, March 8. https://www.theguardian.com/film/2001/mar/09/culture.features.

Hall, S. 1992. "European Cinema on the Verge of a Nervous Breakdown." In Screening Europe: Image and Identity in Contemporary European Cinema, edited by D. Petrie, 45-54. London: British Film Institute.

Hartley, LP. 1953. The Go Between. New York: The New York Review of Books.

Jarman, D. 2010. Chroma: A Book of Color. Minneapolis: University of Minnesota Press.

Lenin, V.I. 27 August 2015. "Lenin on the Most Important of the Arts." Seventeen Moments in Soviet History. http://soviethistory.msu.edu/1924-2/socialist-cinema/socialist-cinema-texts/leninon-the-most-important-of-the-arts/.

Marciniak, K. 2016. Error! Main Document Only.“The Disappearing Classroom: Streaming Foreigners and a Politics of Invisibility." In Teaching Transnational Cinema: Politics and Pedagogy, edited by Katarzyna Marciniak and Bruce Bennett, 268-284. New York: Routledge.

Marciniak, K. 2010. Error! Main Document Only."Pedagogy of Anxiety.” Signs: Journal of Women in Culture and Society 35 (4): 869-892.

Marciniak, K. 2005. Error! Main Document Only. “Second Worldness and Transnational Feminist Practices: Agnieszka Holland's A Woman Alone." In East European Cinemas, edited by Anikó Imre, 3-20. London and New York: Routledge.

Marciniak, K. and B. Bennett. 2016. "Introduction: Teaching Transnational Cinema: Politics and Pedagogy." In Teaching Transnational Cinema: Politics and Pedagogy, edited by Katarzyna Marciniak and Bruce Bennett, 1-37. London and New York: Routledge.

Marciniak, K. and B. Bennett. 2018. "Aporias of Foreignness: Transnational Encounters in Cinema.” Transnational Cinemas 9 (1): 1-12.

Pawlikowski, P., dir. 2017. Cold War. Poland/France/UK: Opus Film/Apocalypso Pictures/MK2 Productions/ARTE France/BFI Film Fund/Canal+Polska/Film4/Kino Świat/MK2 Films/Protagonist Pictures.

Said, E. 2003. Reflections on Exile and Other Essays. Cambridge: Harvard University Press.

Sarkar, B. 2010. "Tracking 'Global Media' in the Outposts of Civilisation." In World Cinemas, Transnational Perspectives, edited by Nataša Durovičová and Kathleen Newman, 34-58. New York and London: Routledge.

Skolimowski, J., dir. 1981. Hands Up! (Ręce do góry). Poland: Arte France Cinéma/PRF Zespół Filmowy/Syrena/Zespół Filmowy. 
Tarkovsky, A. 1987. Sculpting in Time: Reflections on the Cinema. New York: Alfred A. Knopf.

Trinh, M.-H.T., dir. 1989. Surname Viet Given Name Nam. USA: Jean-Paul Bourdier.

Trinh, M.-H.T. 2001. "Not You/Like You: Postcolonial Women and the Interlocking Questions of Identity and Difference." In The Longman Anthology of Women's Literature, edited by Mary K. DeShazer, 928-933. New York: Longman.

Williams, R. 2004. Television: Technology and Cultural Form. London and New York:

Routledge.

Yaeger, P. 1997. “Consuming Trauma; or, The Pleasures of Merely Circulating.” Journal X 2: 225-251. 